\title{
Energy budget of wood-feeding larvae of Corymbia rubra (Coleoptera: Cerambycidae)
}

\author{
AlEKSANDRA WALCZYŃSKA
}

Institute of Environmental Sciences, Jagiellonian University, Gronostajowa 7, 30-387 Kraków, Poland; e-mail: amucha@yahoo.com

Key words. Cerambycidae, Corymbia rubra, assimilation efficiency, bioenergetic parameters, consumption rate, energy budget, energy value, growth rate, larvae, longhorn beetle, metabolism, respiration rate, wood-feeding, xylem-feeding

\begin{abstract}
The energy budget of xylem-feeding Corymbia rubra (Coleoptera: Cerambycidae) larvae was estimated by determining bioenergetic parameters. The values of several of the life history and bioenergetic parameters of this wood-feeding insect are exceptional and associated with specific adaptations to living in and feeding on wood. The energy budget of $C$. rubra sheds light on the life strategy of a xylem-feeder. Its slow growth $\left(0.012 \mathrm{mg} \times \mathrm{mg}^{-1} \times \mathrm{d}^{-1}\right)$ is associated with a low consumption rate $\left(0.097 \mathrm{mg}^{\circ} \mathrm{mg}^{-1}\right.$ $\times \mathrm{d}^{-1}$ ) and the low nutritional value of its food (the assimilation efficiency is $34 \%$ ). The gross growth and net growth efficiency are $15 \%$ and $43 \%$, respectively.
\end{abstract}

\section{INTRODUCTION}

Energy budgets of organisms are constrained by resource acquisition or energy expenditure (Weiner, 1992). Thus, resources partitioned between life history functions in order to maximise fitness are limited and a compromise must always be made, something that Cody (1966, after Price, 1984) formulated as "the principle of allocation".

Diversity in life strategies is caused by differences in consumption and allocation of resources associated with food type (Slansky \& Rodriguez, 1987) and mortality (Kozłowski, 1992). Therefore, each habitat requires specific adaptations. Stem borers are unique with regard to these requirements. Unlike in many other habitats, boring into wood provides organisms with protection from parasites and predators (Fiske, 1908, after Haack \& Slansky, 1987) and sufficient and seasonally invariable amounts of food. However, stem tissues contain polymers that are difficult to digest (e.g. cellulose, lignin) and lack nutrients, especially nitrogen. Thus, animals living inside a tree stem need energetically costly adaptations for food utilisation such as complex enzyme sets, including cellulases unique in the animal world and symbiotic relationships with microorganisms (Haack \& Slansky, 1987). The nutritional quality of a stem decreases towards the centre with the wood (xylem) as the least nutritious tissue (Haack \& Slansky, 1987).

Among terrestrial insects, 7 families of Coleoptera and 2 of Hymenoptera and Lepidoptera live exclusively inside tree stems for at least a part of their life (Haack \& Slansky, 1987). They are characterised by traits that distinguish them from insects in other feeding guilds, namely low growth rates, long developmental times, large body size, low consumption rate and poor food utilisation efficiency (Haack \& Slansky, 1987; Slansky \& Rodriguez, 1987); albeit such data are scarce. Little is known on the metabolic rate of wood-feeders. The existing data, reviewed by Haack \& Slansky (1987), do not allow for an unambiguous description of the life strategy of wood-feeding insects because of both the scarcity of research on this subject and the lack of a coherent methodology for determining their energy budgets.

The ecological energy transfer is usually described by the following equation in ecological energetics (Phillipson, 1975, van Loon, 2005):

$$
C=P+R+F U \text {, }
$$

where: $C$ - total intake of food energy (= consumption), $P$ - energy content of the biomass of materials digested (= production), $R$ - the energy converted to heat and lost in life processes (= respiration), $F$ - the energy content of undigested material (= egesta or faeces), $U$ - the energy content of digested material that is passed from the body (= excreta or urinary wastes). The indices of growth and production efficiencies are assimilation efficiency $E_{A}$, efficiency of conversion of digested food ( $=$ net growth efficiency) $E C D$ and efficiency of conversion of ingested food (= gross growth efficiency) ECI (Waldbauer, 1968; Slansky \& Rodriguez, 1987). Finally, to compare bioenergetic parameters among specimens of different sizes, relative rates of consumption $(R C R)$ and growth $(R G R)$ are calculated (Waldbauer, 1968; Slansky \& Rodriguez, 1987).

The aim of this study was to estimate the bioenergetic parameters of Corymbia rubra (Leptura rubra) (Linnaeus) larvae (Coleoptera: Cerambycidae). They spend their whole life inside dead trees, mostly pine and feed on the cellulose in the xylem. As previously mentioned, this type of food is extremely poor in nutrients and the insects that feed on it have specific adaptations (Haack \& Slansky, 1987). Thus, C. rubra, a typical xylem-feeder, is a promising subject for research on the bioenergetic strategy of wood-feeders.

In the present study, the relationships between respiration, growth and production rates and body mass in $C$. 
rubra larvae were measured in 2002, and, in 2006 the consumption rate and energy value were assessed. Based on this species energy budget, conclusions were drawn on its energetic adaptations for living in a stem environment.

\section{MATERIAL AND METHODS}

\section{Beetle}

Adults of Corymbia rubra emerge from June to September. A female lays up to 700 eggs in holes in the stems of trees. The larvae feed initially on sapwood and, later, on heartwood (Dominik \& Starzyk, 2004). They moult several times. The whole lifecycle lasts $1-3$ years, mostly 2-3 years (Dominik \& Starzyk, 2004).

\section{Material}

In autumns of 2001 and 2005/2006, stumps of pine trees cut 3-5 years earlier were collected from the Niepołomice Forest near Krakow, Poland. In 2001/2002 the stumps were kept for several months under laboratory conditions at a constant temperature of $17^{\circ} \mathrm{C}$ in a dark room. For the experiments, larvae of C. rubra were removed from the stumps, and kept at $17^{\circ} \mathrm{C}$ in separate plastic Coulter containers (Beckman Coulter, USA) with moistened gypsum mixed with active carbon and provided with pinewood as food. The containers were kept in a closed plastic breeding box (approx. 601 ) the bottom of which was lined with moist gypsum to maintain a high humidity. Respiration, production and growth rates were measured.

Larvae from stumps collected in 2005/2006 were used for estimating energy content and consumption rates.

\section{Respiration rate}

Respiration rate was measured using a MicroOxymax respirometer (Columbus, Ohio, USA). Larvae taken from the breeding box $(\mathrm{N}=78)$ were weighed and those of similar mass were placed in plastic test tubes containing moist gypsum and cubes of pinewood. Then, test tubes $(\mathrm{N}=16)$ containing 4-7 larvae were placed in $500 \mathrm{ml}$ glass containers. The control containers with only moist gypsum and cubes of pinewood were tested at the same time. All the containers were kept at $17^{\circ} \mathrm{C}$ in the dark. Respiration rate was measured twice, using different larvae. The accumulative $\mathrm{CO}_{2}$ production over 4.5 days $\left(\mathrm{ml} \mathrm{CO} \times \mathrm{d}^{-1}\right)$ in each trial was used in the analyses.

\section{Energy value}

In 2002, mixed pinewood samples $(\mathrm{n}=6 ; 0.0030-0.0223 \mathrm{~g}$ of dry mass) were dried for $24 \mathrm{~h}$ at $105^{\circ} \mathrm{C}$ and burnt in a calorimetric microbomb calibrated with benzoic acid of known energy value. In 2006, beetle larvae $(\mathrm{N}=17,0.0186-0.193 \mathrm{~g}$ of dry mass) were exposed to $-70^{\circ} \mathrm{C}$ for an hour and then dried at $60^{\circ} \mathrm{C}$ for $2 \mathrm{~h}$. The dry body mass was determined for each specimen using a moisture analyzer Mettler Toledo HR73 just before measuring the energy content. Dry larvae were formed into pellets and burnt in a calorimetric microbomb calibrated with benzoic acid of known energy value. If the pellet exceeded the mass suitable for analysis $(0.08 \mathrm{~g})$ then it was split into twothree subsamples and the average energy per unit mass was calculated. The energy content of a sample $\left(\mathrm{kJ} \times \mathrm{g}^{-1}\right.$ of dry mass $)$ was determined using a calibration curve.

\section{Growth and production rates}

Growth rate was estimated as the difference in body mass (precision of measurements $=0.1 \mathrm{mg}$ ) after 19 days for all the larvae that survived $(\mathrm{N}=75)$. Assuming that growth rate of insect larvae is exponential (e.g. D'Amico et al., 2001) it can be described as follows:

$$
M_{T}=M_{0} \times e^{T \times R G R},
$$

where: $M_{T}$ - body mass at time T, $M_{0}$ - body mass at time $0, e-$ base of natural logarithm, $T$ - time period from 0 to T, $R G R-$ relative growth rate coefficient. The value of the $R G R$ parameter can be calculated using:

$$
R G R=\left(\ln M_{T}-\ln M_{0}\right) / T .\left(\mathrm{g} \times \mathrm{g}^{-1} \times \mathrm{d}^{-1}\right)
$$

This formula is used for estimating the growth rate parameter of insects, including wood-feeders (e.g. Hosking \& Hutcheson, 1979). The increase in body mass over 19 days was also used for estimating the production rate $\left(\mathrm{g} \times \mathrm{d}^{-1}\right)$.

\section{Consumption rate}

Consumption rate was measured in 2006. Larvae of different sizes were placed in rectangular $(150 \times 160 \times 5 \mathrm{~mm})$ slices of pinewood, sandwiched between two $3 \mathrm{~mm}$ glass sheets and closed with PVC tape (Hosking \& Hutcheson, 1979). These rearing units were kept at one of three different temperatures $(11.4 \pm 0.3 \mathrm{SD}, 21.1 \pm 2.6 \mathrm{SD}$ and $24.2 \pm 0.2 \mathrm{SD}$ centigrades $)$. After two months, the area of the larval galleries was estimated by measuring their area on scanned slices $(\mathrm{N}=45)$ using ImageJ software (National Institute of Health, USA) and multiplying it by the gallery's thickness measured using millimetre graph paper. Consumption rate was estimated by subtracting the mass of faeces and pinedust from the gallery mass, calculated from gallery volume (average mass density of pinewood $=0.49$ $\mathrm{mg} / \mathrm{mm}^{3}$; Surmiński, 1993), and dividing it by the number of days each larva was kept in a rearing unit. Moreover, because the estimations in 2002 were carried out at $17^{\circ} \mathrm{C}$, consumption rate at this temperature was determined using the following formula (Schmidt-Nielsen, 1990):

$$
C_{17}=C_{T} \times Q 10^{\wedge}((17-T) / 10),\left(\mathrm{mg} \times \mathrm{d}^{-1}\right)
$$

where: $C_{17}$ - consumption rate at $17^{\circ} \mathrm{C}, C_{T}$ - consumption rate at experimental temperature, $Q 10$ - temperature coefficient indicating the rate of change of biological processes as a consequence of increasing the temperature by $10^{\circ} \mathrm{C}, T$ - experimental temperature. A $Q 10$ value of 2.25 was assumed, which is the average of the 2.0-2.5 range of ectothermic Q10s (Withers, 1992, after Duncan \& Dickman, 2001).

\section{Assimilation and growth efficiencies}

The mean values of the production, respiration and consumption rates were converted to $\mathrm{J} \times \mathrm{g}^{-1} \times \mathrm{d}^{-1}$ units. The production and consumption rates were calculated using the energy content of $1 \mathrm{~g}$ of biomass of larvae or wood, respectively, and the respiration data, assuming that for a carbohydrate diet $\mathrm{RQ}=1$ and that the oxycalorific equivalent is $5.0 \mathrm{cal} / \mathrm{ml} \mathrm{O}_{2}$ (SchmidtNielsen, 1990). Using this data, assimilation, gross and net growth efficiencies were calculated according to the following formulas:

$$
E_{A}=(P+R) / C,
$$

where: $E_{A}$ - assimilation efficiency; $P$ - production rate, $R$ - respiration rate, $C$ - consumption rate;

$$
E C I=P / C \text {, }
$$

where: $E C I$ - gross growth efficiency, $P$ - production rate, $C-$ consumption rate, and

$$
E C D=P /(P+R),
$$

where: $E C D$ - net growth efficiency, $P$ - production rate, $R-$ respiration rate.

\section{Statistical analyses}

The equations were fitted to data using Statistica 7.1; a Simple Regression Model was used for linear data and a Nonlinear Regression Model (least squares) for other data. 


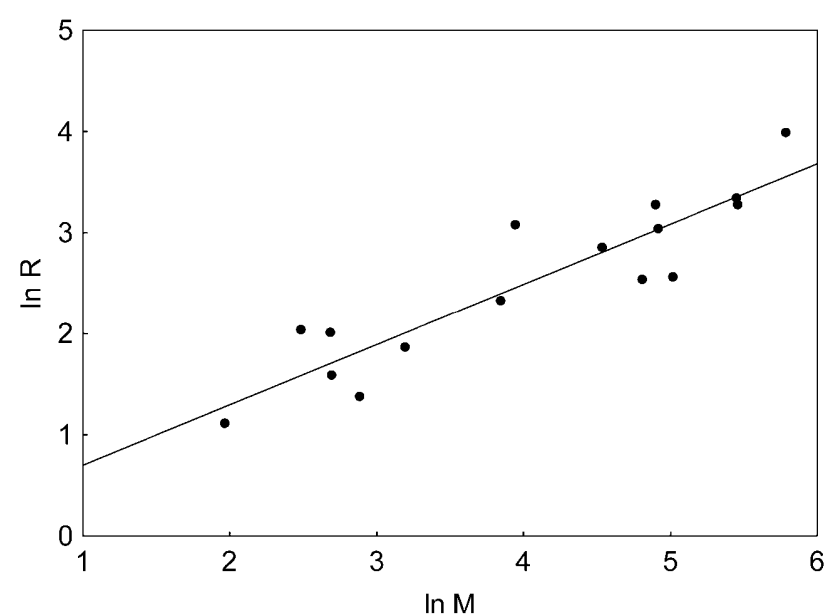

Fig. 1. The logarithmic relationship between respiration rate $\left(\mu \mathrm{l} \mathrm{CO} \mathrm{CO}_{2} \times\right.$ ind $\left.^{-1} \times \mathrm{h}^{-1}\right)$ and average body mass $(\mathrm{mg})$ of the 4-7 larvae in each tube.

\section{RESULTS}

\section{Respiration rate}

The relationship between respiration rate and the mean mass of groups of larvae is:

$$
\mathrm{R}=99.7 \times \mathrm{M}^{0.77}(\mu \mathrm{l} \mathrm{CO} / \mathrm{h})
$$

$\left[\mathrm{R}^{2}=0.78 ; \mathrm{p}\right.$ (exponent estimation) $=0.00011 ; 95 \%$ confidence intervals for the exponent: $0.46-1.08]$. The logarithmic relationship between respiration rate and the average body mass in each tube is shown in Fig. 1.

\section{Energy value}

The energy value scales linearly with the dry mass of pelleted larvae $\left(\mathrm{R}^{2}=0.97 ; \mathrm{p}<0.0001\right.$, Fig. 2), indicating that the ratio is constant and does not change with larval size. Thus, the average value of $23.5 \mathrm{~kJ} / \mathrm{g}$ of dry mass $(6.8 \mathrm{~kJ} / \mathrm{g}$ of biomass; water content $=70.7 \pm 5.1 \mathrm{SD} \%)$ is considered to be the energy equivalent of $C$. rubra larvae. The energy value of mixed samples of pinewood is 16.7 $\mathrm{kJ} / \mathrm{g}$ of dry mass $(6.85 \mathrm{~kJ} / \mathrm{g}$ of biomass; water content $=$ $58.9 \pm 14.6 \mathrm{SD} \%)$.

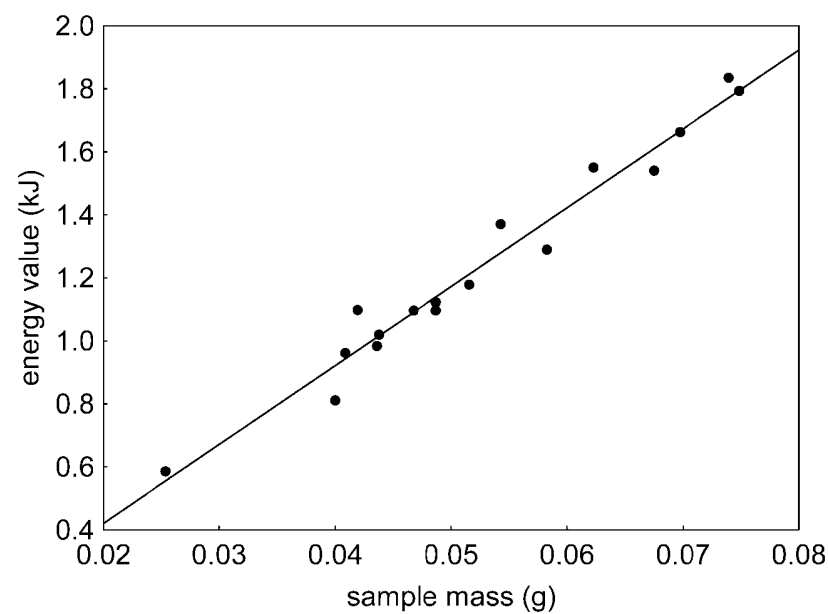

Fig. 2. The relationship between the energy value and the dry mass of the sample of larvae.

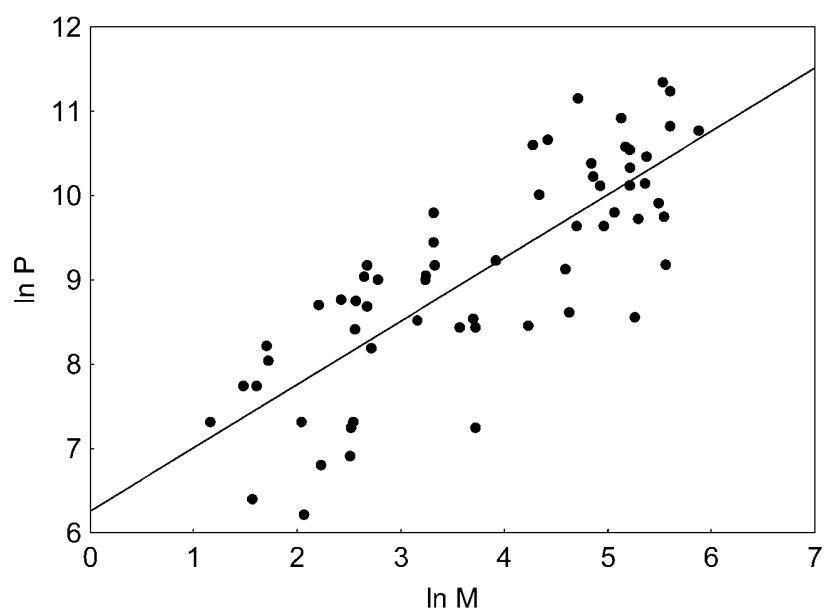

Fig. 3. The logarithmic relationship between production $(\mu \mathrm{g})$ measured over 19 days and body mass (mg) of individuals.

\section{Growth and production rates}

The average body mass of larvae at the beginning of the experiment was 0.092 (range $=0.003-0.359$ ) g. Because the objective was to determine the continuous production rate during an intermoult period, larvae that moulted $(\mathrm{N}=$ 11 ) or lost mass for unknown reasons $(\mathrm{N}=2)$ were not included in the analysis. The RGR value was $0.0121 \pm$ $0.0078 \mathrm{SD} \mathrm{mg} \times \mathrm{mg}^{-1} \times \mathrm{d}^{-1}(0.0014-0.027 ; \mathrm{N}=62)$. The relationship between the increase in body mass over 19 days (production $-\mathrm{P}$ ) and individual body mass $(\mathrm{M})$ is:

$$
\mathrm{P}=0.10 \times \mathrm{M}^{0.67}(\mathrm{~g})
$$

$\left[\mathrm{R}^{2}=0.50 ; \mathrm{p}\right.$ (exponent estimation) $=0.000005 ; 95 \%$ confidence interval for the exponent: $0.40-0.94]$. The logarithmic relationship between production rate and body mass of individuals is shown in Fig. 3.

\section{Consumption rate}

The average consumption rate is $0.097 \mathrm{~g} \times \mathrm{g}^{-1} \times \mathrm{d}^{-1}$. The following relationship between consumption rate and body mass of larvae was found:

$$
\mathrm{C}=24.5 \times \mathrm{M}^{0.47}(\mathrm{mg} / \mathrm{d})
$$

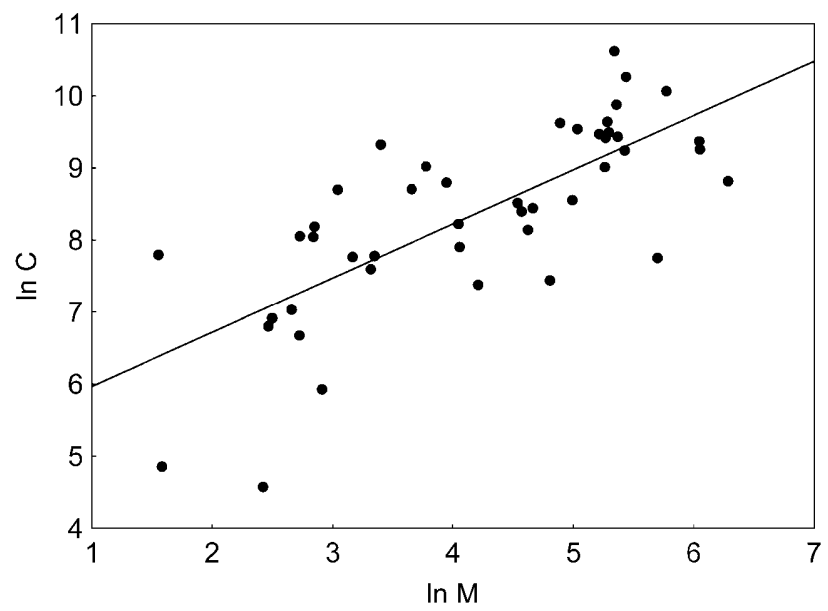

Fig. 4. The logarithmic relationship between consumption rate $\left(\mu \mathrm{g} \times \mathrm{d}^{-1}\right)$ and body mass $(\mathrm{mg})$ of individuals. 
TABLE 1. The mean RGR, assimilation and production efficiency values for insects in different feeding guilds. $\mathrm{N}-$ indicates sample size (species or different food types within a species); values given in references as ranges were excluded from calculations.

\begin{tabular}{|c|c|c|c|c|c|}
\hline feeding type & $\begin{array}{c}\mathrm{RGR} \\
\left(\mathrm{mg} \times \mathrm{mg}^{-1} \times \mathrm{d}^{-1}\right)\end{array}$ & $\begin{array}{l}\text { assimilation } \\
\text { efficiency (\%) }\end{array}$ & $\begin{array}{l}\text { gross growth } \\
\text { efficiency }(\%)\end{array}$ & $\begin{array}{c}\text { net growth } \\
\text { efficiency (\%) }\end{array}$ & references \\
\hline $\begin{array}{l}\text { forb foliage-chewing } \\
\text { (N) }\end{array}$ & $\begin{array}{c}0.37 \\
(180)\end{array}$ & - & - & - & Tabashnik \& Slansky, 1987 \\
\hline $\begin{array}{l}\text { folivores of woody plants * } \\
\text { (N) }\end{array}$ & $\begin{array}{l}0.05-0.15 \\
(?)\end{array}$ & - & $\begin{array}{l}5-15 \\
(?)\end{array}$ & - & Mattson \& Scriber, 1987 \\
\hline $\begin{array}{l}\text { grass-feeding } * * \\
(\mathrm{~N})\end{array}$ & - & $\begin{array}{l}44 \pm 16 \\
(41)\end{array}$ & - & $\begin{array}{l}34 \pm 15 \\
(35)\end{array}$ & Bernays \& Barbehenn, 1987 \\
\hline $\begin{array}{l}\text { stored-products feeding } \\
(\mathrm{N})\end{array}$ & $\begin{array}{l}0.17 \pm 0.04 \\
\quad(20)\end{array}$ & $\begin{array}{l}77 \pm 11 \\
(25)\end{array}$ & $\begin{array}{r}9 \pm 7 \\
(25)\end{array}$ & $\begin{array}{l}11 \pm 8 \\
(25)\end{array}$ & Baker \& Loschiavo, 1987 \\
\hline $\begin{array}{l}\text { predaceous, terrestrial } \\
(\mathrm{N})\end{array}$ & $\begin{array}{c}0.01(0.002-0.02) \\
(?)\end{array}$ & $\begin{array}{c}86(37-98) \\
(?)\end{array}$ & $\begin{array}{c}39(4-75) \\
(?)\end{array}$ & $\begin{array}{c}34(4-64) \\
(?)\end{array}$ & Hagen, 1987 \\
\hline $\begin{array}{l}\text { xylo- and cambiophagous } \\
\text { (N) }\end{array}$ & $\begin{array}{l}0.02 \pm 0.02 \\
\quad \text { (3) }\end{array}$ & $\begin{array}{l}29 \pm 19 \\
\quad(6)\end{array}$ & $\begin{array}{c}21 \pm 15 \\
(8)\end{array}$ & $\begin{array}{l}35 \\
(1)\end{array}$ & Haack \& Slansky, 1987 \\
\hline xylophagous C. rubra & 0.012 & 34 & 15 & 43 & present study \\
\hline
\end{tabular}

* data for north temperate saturniids; ** means for polyphagous and graminivorous species.

$\left[\mathrm{R}^{2}=0.33 ; \mathrm{p}\right.$ (exponent estimation) $=0.0012 ; 95 \%$ confidence interval for the exponent: $0.20-0.74]$. The logarithmic relationship between consumption rate and body mass of individuals is shown in Fig. 4.

\section{Assimilation and growth efficiencies}

Using equation (1) the energy budget of an average $C$. rubra larva was estimated as:

$$
666.8=97.5+129.2+440.1\left(\mathrm{~J} \times \mathrm{g}^{-1} \times \mathrm{d}^{-1}\right) .
$$

According to formulas (5)-(7), the assimilation efficiency is $34 \%$ while gross and net growth efficiencies are $15 \%$ and $43 \%$, respectively (Table 1 ).

\section{DISCUSSION}

The complete energy budget of $C$. rubra larvae determined in this study reveal valuable information about its life strategy. Changes in energy budget parameters (production, respiration and consumption rates, and energy values) were monitored for a wide range of body masses.

The mass-independent metabolic rate of $C$. rubra larvae, recalculated according to Kleiber (1932, after Reinhold, 1999), is $0.11 \pm 0.05\left(\mathrm{ml} \mathrm{O}_{2} \times \mathrm{g}^{-0.75} \times \mathrm{h}^{-1}\right)$, while this value for several species of Coleoptera is about $0.76 \mathrm{ml} \mathrm{O}_{2} \times \mathrm{g}^{-0.75} \times \mathrm{h}^{-1}$ for flying- and about $0.20 \mathrm{ml} \mathrm{O}_{2} \times$ $\mathrm{g}^{-0.75} \times \mathrm{h}^{-1}$ for non-flying species (Reinhold, 1999). Therefore, the metabolic rate of C. rubra larvae is relatively low compared to that of other Coleoptera.

The energy value for C. rubra, measured using a standard method, is greater than that of desert cerambycids $(19.7 \mathrm{~kJ} / \mathrm{g}$ d.m.; Chen et al., 2004) but similar to that of other beetles: $25 \mathrm{~kJ} / \mathrm{g}$ for carabids (Maryański et al., 2002) and $21 \mathrm{~kJ} / \mathrm{g}$ for adult beetles from an arid environment (Chen et al., 2004).

The relative consumption rate of C. rubra is similar to that of the wood-feeder Anobium punctatum $(0.1 \mathrm{mg} \times$ $\mathrm{mg}^{-1} \times \mathrm{d}^{-1}$, Baker et al., 1970, after Haack \& Slansky, 1987), but low in the recorded range of insect consumption rates of $0.002-6.90 \mathrm{mg} \times \mathrm{mg}^{-1} \times \mathrm{d}^{-1}$ (Slansky \& Scriber, 1985, after Slansky \& Rodriguez, 1987). It could be caused by the long time needed for processing and digesting wood.

The RGR values and production and assimilation efficiencies of $C$. rubra compared to insects from other feeding guilds are shown in Table 1. Although this interspecific comparison should be treated with caution because the parameters could be measured or calculated in different ways, the general pattern is that RGR increases with the nutritional value of the food. The exceptionally low RGR of predaceous insects is probably associated with their low consumption rate (Hagen, 1987). Stored-product insects have relatively low RGRs in spite of very high assimilation efficiencies, which may be because of high energetic costs of producing and utilizing of metabolic water (stored-products are a very dry food). Their very low net growth efficiency accords with this idea. The net growth efficiency of C. rubra is higher than that of stored-product insects, but its RGR is much lower. The relatively low assimilation efficiency implies that the growth rate of $C$. rubra is limited by the low nutritional quality of its food. They need to process large amounts of food in order to obtain sufficient nutrients for growth. Thus, the low nutritional quality of wood, together with the consumption rate, limit C. rubra's life strategy, resulting in the low growth rate and long developmental time of the larvae. On the other hand, this developmental strategy may be due to low predatory pressure (Haack \& Slansky, 1987). If the rate of mortality of larvae were high, then developing for several seasons in order to achieve the desired size at maturity would not be possible.

The present study is the first attempt to describe an insect life strategy in terms of the energy budget of its larvae. It shows that the larvae of the wood-feeder, C. rubra, grows slowly and have a low metabolic rate compared to species in other feeding guilds and that these are consequences of the low nutritional quality of wood (relatively low assimilation efficiency) and a low consumption rate, rather than high metabolic costs associated with processing wood (relatively high net growth efficiency). 
ACKNOWLEDGEMENTS. I thank J. Weiner for his comments and encouragement throughout this study, J. Starzyk for introducing me to the subject of wood-feeding insects, A. Kędziorski and B. Łozowski for help in obtaining the energy content measurements, M. Czarnołęski, J. Rutkowska, P. Skórka, H. Szentgyörgyi, M. Witek and three anonymous referees for helpful comments on previous versions of the manuscript and a forest inspector, S. Sennik, for permission to work in the Niepołomice Forest. The work was partly supported by the Polish Ministry of Scientific Research and Information Technology, grant 2 P04C 08328.

\section{REFERENCES}

BAKer J.E. \& Loschiavo S.R. 1987: Nutritional ecology of stored-product insects. In Slansky F.Jr. \& Rodriguez J.G. (eds): Nutritional Ecology of Insects, Mites, Spiders and Related Invertebrates. John Wiley \& Sons, London, New York, pp. 321-344.

BaKer J.M., LAidLAW R.A. \& SMith G.A. 1970: Wood breakdown and nitrogen utilization by Anobium punctatum DeG. feeding on Scots pine sapwood. Holzforschung 24: 45-54.

Bernays E.A. \& BarbehenN R. 1987: Nutritional ecology of grass foliage-chewing insects. In Slansky F.Jr. \& Rodriguez J.G. (eds): Nutritional Ecology of Insects, Mites, Spiders and Related Invertebrates. John Wiley \& Sons, London, New York, pp. 147-175.

Chen X., Thompson M.B. \& Dickman C.R. 2004: Energy density and its seasonal variation in desert beetles. J. Arid Env. 56: 559-567.

Cody M.L. 1966: A general theory of clutch size. Evolution 20: $174-184$

D’Amico L.J., Davidovitz G. \& Nishout H.F. 2001: The developmental and physiological basis of body size evolution in an insect. Proc. R. Soc. Lond. (B) 268: 1589-1593.

Dominik J. \& StARzYK J.R. 2004: Wood Damaging Insects. PWRiL, Warsaw, 584 pp. [in Polish].

DunCAN F.D. \& Dickman C.R. 2001: Respiratory patterns and metabolism in tenebrionid and carabid beetles from the Simpson Desert, Australia. Oecologia 129: 509-517.

FISKE W.F. 1908: Notes on insect enemies of wood boring Coleoptera. Proc. Entomol. Soc. Wash. 9: 23-27.

HAACK R.A. \& SLANSKY F.JR. 1987: Nutritional ecology of wood-feeding Coleoptera, Lepidoptera and Hymenoptera. In Slansky F.Jr. \& Rodriguez J.G. (eds): Nutritional Ecology of Insects, Mites, Spiders and Related Invertebrates. John Wiley \& Sons, London, New York, pp. 449-486.

HAGEN K.S. 1987: Nutritional ecology of terrestrial insect predators. In Slansky F.Jr. \& Rodriguez J.G. (eds): Nutritional Ecology of Insects, Mites, Spiders and Related Invertebrates. John Wiley \& Sons, London, New York, pp. 533-577.

Hosking G.P. \& Hutcheson J.A. 1979: Nutritional basis for feeding zone preference of Arhopalus ferus (Coleoptera: Cerambycidae). New Zeal. J. For. Sci. 9: 185-192.

KleIBER M. 1932: Body size and metabolism. Hilgardia 6: $315-353$.
Kozłowski J. 1992: Optimal allocation of resources to growth and reproduction: implication for age and size at maturity. Trends Ecol. Evol. 7: 15-19.

LoON J.J.A. van 2005: Nutritional ecology of insect-plant interactions: persistent handicaps and the need for innovative approaches. Oikos 108: 194-201.

MaryańsKi M., Kramarz P., Laskowski R. \& NiklińsKa M. 2002: Decreased energetic reserves, morphological changes and accumulation of metals in carabid beetles (Poecilus cupreus L.) exposed to zinc- or cadmium contaminated food. Ecotoxicology 11: 127-139.

MATTSON W.J. \& SCRIBER J.M. 1987: Nutritional ecology of insect folivores of woody plants: nitrogen, water, fiber and mineral considerations. In Slansky F.Jr. \& Rodriguez J.G. (eds): Nutritional Ecology of Insects, Mites, Spiders and Related Invertebrates. John Wiley \& Sons, London, New York, pp. 105-146.

Phillipson J. 1975: Introduction to ecological energetics. In Grodziński W., Klekowski R.Z. \& Duncan A. (eds): Methods for Ecological Bioenergetics. Blackwell, Oxford, pp. 3-13.

Price P.W. 1984: Insect Ecology. 2nd ed. John Wiley \& Sons, New York, 607 pp.

REINHOLD K. 1999: Energetically costly behaviour and the evolution of resting metabolic rate in insects. Funct. Ecol. 13: 217-224.

Schmidt-Nielsen K. 1990: Animal Physiology: Adaptation and Environment. 4th ed. Cambridge University Press, Cambridge, $601 \mathrm{pp}$.

Slansky F.JR. \& SCRIBER J.M. 1985: Food consumption and utilization. In Kerkut G.A. \& Gilbert L.I. (eds): Comprehensive Insect Physiology, Biochemistry and Pharmacology. Vol. 4. Pergamon Press, Oxford, pp. 87-163.

SlANSKY F.JR. \& Rodriguez J.G. 1987: Nutritional ecology of insects, mites, spiders and related invertebrates: an overview. In Slansky F.Jr. \& Rodriguez J.G. (eds): Nutritional Ecology of Insects, Mites, Spiders and Related Invertebrates. John Wiley \& Sons, London, New York, pp. 1-69.

SURMIŃSKI J. 1993: Technical characteristics and use abilities. In Białobok S., Boratyński A. \& Bugała W. (eds): Biology of Scots Pine. Sorus, Poznań-Kórnik, pp. 443-468 [in Polish].

TABashnik B.E. \& Slansky F.JR. 1987: Nutritional ecology of forb foliage-chewing insects. In Slansky F.Jr. \& Rodriguez J.G. (eds): Nutritional Ecology of Insects, Mites, Spiders and Related Invertebrates. John Wiley \& Sons, London, New York, pp. 71-103.

WaLdBAUER G.P. 1968: The consumption and utilization of food by insects. Adv. Insect Physiol. 5: 229-289.

WeINER J. 1992: Physiological limits to sustainable energy budgets in birds and mammals: ecological implications. Trends Ecol. Evol. 7: 384-388.

Withers P.C. 1992: Comparative Animal Physiology. Saunders College, Fort Worth, $1088 \mathrm{pp}$.

Received August 31, 2005; revised and accepted November 10, 2006 